\title{
ANALISIS HASIL PERTANIAN DI KOTA DENPASAR DENGAN MENGGUNAKAN SISTEM INFORMASI GEOGRAFIS
}

Ni Nyoman Supuwiningsih

Program Studi Sistem Komputer

Jl. Puputan No. 86 Renon Denpasar

e-mail : comank2002@yahoo.com

\begin{abstract}
Agriculture is an activity in utilizing natural resources made by humans so that they can produce food, raw materials for industrial enterprises, energy and natural balance. Imagine if a country's territory there is no agricultural land as a strategic sector or agricultural land into residential land entirely different functions then the country can not meet the primary needs due to hold human life in need of food. Food is a primary need of agricultural products should need to be increased the number of its production due to offset population. The limited agricultural land in Denpasar from year to year will affect agricultural output. Based on these problems will require analysis of agricultural products in order to determine the increase or decrease in agricultural output in Denpasar using geographic information systems and GIS ArcView 3.3 as tools that can be used as an ingredient in decision making by the government. The method used in this research is the collection of spatial data and non-spatial data, data analysis of agricultural products in their respective districts in the city of Denpasar, database creation and conduct digitized into a digital map. Results from this study is a digital map that provides information on the increase or decrease of agricultural output in 2011-2014 in each district in the city of Denpasar.
\end{abstract}

Keywords : Agriculture, GIS, spatial data and non-spatial data, digital map

\begin{abstract}
Abstrak
Pertanian merupakan aktivitas dalam memanfaatkan sumber daya alam yang dilakukan oleh manusia sehingga dapat menghasilkan bahan makanan, bahan baku untuk perusahaan industri, energi dan dapat menyeimbangkan alam. Bayangkan jika pada suatu negara wilayahnya tidak terdapat lahan pertanian sebagai sektor strategis atau lahan pertanian yang seluruhnya beralihfungsi menjadi lahan pemukiman maka negara tersebut tidak bisa memenuhi kebutuhan primer karena untuk melangsungkan hidupnya manusia membutuhkan pangan. Pangan merupakan kebutuhan primer dari hasil pertanian yang sebaiknya perlu ditingkatkan jumlah produksinya karena mengimbangi jumlah penduduk. Semakin sempitnya lahan pertanian di Kota Denpasar dari tahun ke tahun akan mempengaruhi hasil pertanian. Berdasarkan permasalahan tersebut maka diperlukan analisis mengenai hasil pertanian dengan tujuan untuk mengetahui peningkatan atau penurunan hasil pertanian di Kota Denpasar dengan menggunakan sistem informasi geografi dan ArcView GIS 3.3 sebagai tools sehingga dapat digunakan sebagai bahan dalam pengambilan keputusan oleh pemerintah. Metode yang digunakan dalam penelitian ini adalah pengumpulan data spasial dan data non spasial, analisis data hasil pertanian di masing-masing kecamatan di Kota Denpasar, pembuatan database dan melakukan digitasi ke dalam peta digital. Hasil dari penelitian ini adalah peta digital yang memberikan informasi mengenai peningkatan atau penurunan hasil pertanian dari tahun 20112014 di masing-masing kecamatan di Kota Denpasar.
\end{abstract}

Kata Kunci : Pertanian, GIS, data spasial dan data non spasial

\section{PENDAHULUAN}

Pertanian merupakan aktivitas dalam memanfaatkan sumber daya alam yang dilakukan oleh manusia sehingga dapat menghasilkan bahan makanan, bahan baku untuk perusahaan industri, energi dan dapat menyeimbangkan alam (Pertanian, K. 2013). Bayangkan jika pada suatu negara wilayahnya tidak terdapat lahan pertanian sebagai sektor strategis atau lahan pertanian yang seluruhnya beralihfungsi menjadi lahan pemukiman maka negara tersebut tidak bisa memenuhi kebutuhan primer karena untuk melangsungkan hidupnya manusia 
membutuhkan pangan. Pangan merupakan kebutuhan primer dari hasil pertanian yang sebaiknya perlu ditingkatkan jumlah produksinya karena mengimbangi jumlah penduduk. Untuk itu diperlukan analisis mengenai hasil pertanian dengan tujuan untuk mengetahui peningkatan atau penurunan hasil pertanian di Kota Denpasar dengan menggunakan sistem informasi geografi dan ArcView GIS 3.3 sebagai tools sehingga dapat digunakan sebagai bahan dalam pengambilan keputusan oleh pemerintah. Data hasil pertanian yang digunakan dalam penelitian ini dari mulai dari tahun 2011 dan data terakhir pada tahun 2014, yang diperoleh dari badan statistik khususnya di bidang pertanian dan sekitar rentang tahun tersebut Kota Denpasar menyusun Rencana Strategis Dinas Pertanian Tanaman Pangan dan Hortikultura (Denpasar, P. k. 2015).

Penelitian ini adalah penelitian lanjutan dari penelitian internal tahap 2 tahun 2015 yang berjudul "Implementasi Geographic Information System untuk pemetaan lahan pertanian di Kota Denpasar", berdasarkan hasil penelitian tersebut berupa pemetaan lahan pertanian ditemukan bahwa lahan pertanian di Kota Denpasar semakin menyempit dari tahun ke tahun karena pertanian tidak menjanjikan lagi sebagai mata pencaharian sehingga sebagian besar lahan pertanian beralihfungsi menjadi pemukiman/tempat berbisnis/kos-kosan, untuk itu diperlukan analisis lebih mendalam mengenai hubungan antara lahan pertanian dengan hasil pertanian di Kota Denpasar sehingga memungkinkan dilakukan sistem pertanian modern yang berkolaborasi dengan IPTEK sebagai solusi serta didukung oleh pemerintah demi menyelamatkan keutuhan lahan pertanian sebagai sektor strategis suatu negara yang diimplementasikan dengan sistem informasi geografis dalam bentuk peta digital. Analisis hasil pertanian menggunakan konsep sistem informasi geografis dengan menggunakan tools software ArcView GIS 3.3.

Metode yang digunakan dalam penelitian ini adalah pengumpulan data spasial dan data non spasial, analisis data hasil pertanian di masing-masing kecamatan di Kota Denpasar, pembuatan data non spasial dan melakukan digitasi ke dalam peta digital. Hasil dari penelitian ini adalah peta digital yang memberikan informasi mengenai peningkatan atau penurunan hasil pertanian dari tahun 2011-2014 di masing-masing kecamatan di Kota Denpasar.

\section{METODE PENELITIAN}

Pada bab ini dibahas mengenai model konseptual penelitian, sistematika penelitian, waktu dan tempat penelitian, data dan teknik analisis.

\subsection{Sistematika Penelitian}

Penelitian ini terdiri dari beberapa tahapan yaitu

1. Studi Literatur

Melakukan studi dengan cara penelusuran informasi dari website situs resmi pemerintah terutama badan statistik hasil pertanian pada masing-masing kecamatan di Kota Denpasar, buku-buku yang berhubungan pertanian, buku tutorial penggunaan software ArcView, studi literatur mengenai konsep dasar-dasar Sistem Informasi Geografis dan jurnal-jurnal yang berhubungan dengan penelitian ini.

2. Pengumpulan data

Melakukan pengumpulan data-data yang dibutuhkan dalam sistem yang berhubungan dengan hasil pertanian berdasarkan jenis lahan pertanian yang teridentifikasi. Data hasil pertanian yang akan diolah adalah dari tahun 2011-2014.

3. Pengelompokkan hasil pertanian

Melakukan pengelompokkan hasil pertanian berdasarkan jenis lahan pertanian pada masing-masing kecamatan di Kota Denpasar dari tahun 2011-2014.

4. Proses analisis data hasil pertanian

Proses ini melakukan identifikasi data spasial dan data non spasial hasil pertanian pada masing-masing kecamatan di Kota Denpasar kemudian melakukan analisis data spasial dan data non spasial hasil pertanian dan luas lahan pertanian masing-masing kecamatan tersebut.

5. Proses identifikasi layer dan pembuatan tabel

Dari analisis data maka dapat diimplementasikan dalam ArcView dengan mengidentifikasi layer dalam format data vector dan pembuatan tabel pada masing-masing layer. 
6. Proses digitasi Melakukan proses digitasi ke dalam bentuk peta digital dengan format vector. Sistematika penelitian dapat dilihat pada gambar 1

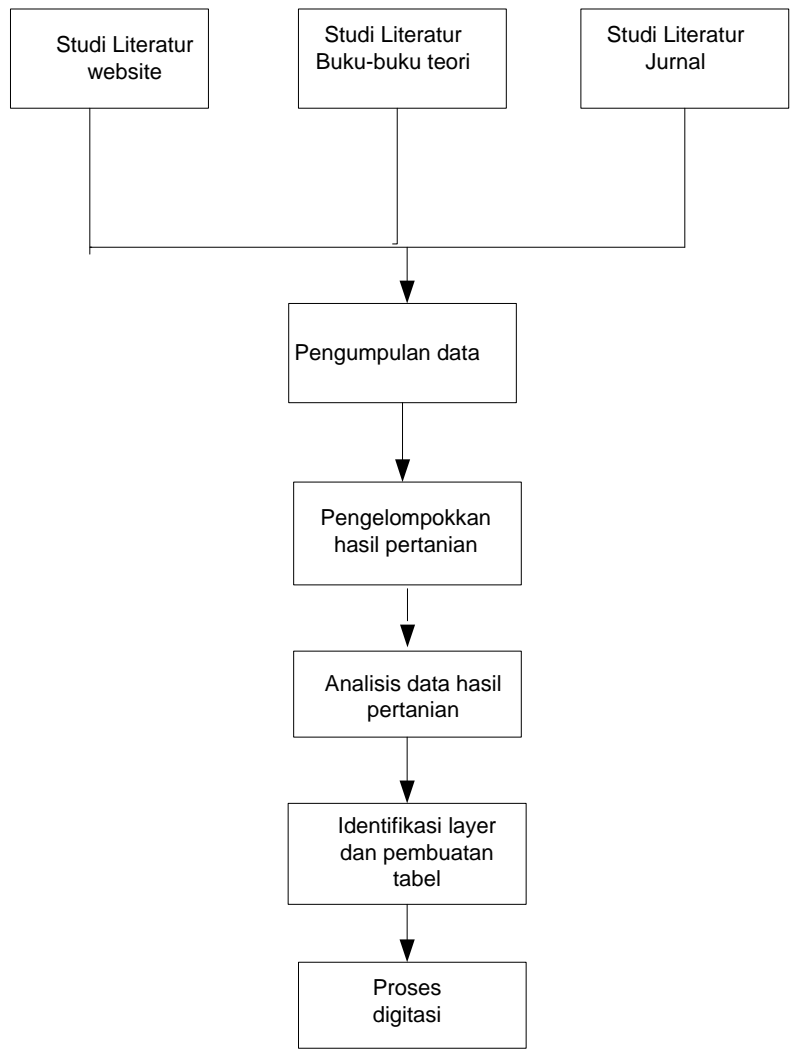

Gambar 1 Sistematika Penelitian

\section{Hasil Penelitian dan Pembahasan}

\subsection{Hasil Pertanian di Kecamatan Denpasar Timur}

Lahan pertanian dikelompokkan menjadi 3 yaitu lahan sawah, tegalan dan perkebunan. Penelitian pertama dilakukan pada Kecamatan Denpasar Timur, luas wilayah Kecamatan ini sekitar $22.31 \mathrm{~km}^{2}$, dari luas wilayah tersebut terdapat luas lahan pertanian, berdasarkan data yang didapat dari badan statistik pertanian, di wilayah ini dari tahun 2011-2014 mengalami penyempitan luas pertanian. Penyempitan luas pertanian yang signifikan di tahun 2014, penurunan luas lahan pertanian dari tahun sebelumnya sekitar $52.15 \%$.

Tabel 1. Perbandingan Luas Lahan Pertanian di Kecamatan Denpasar Timur

\begin{tabular}{|l|c|c|c|c|}
\hline \multirow{2}{*}{ Tahun } & \multicolumn{3}{|c|}{ Jenis Lahan Pertanian $\left(\mathrm{km}^{2}\right)$} & \multirow{2}{*}{ Total $\left(\mathrm{km}^{2}\right)$} \\
\cline { 2 - 4 } & Sawah & Tegalan & Perkebunan & \\
\hline 2011 & 6.94 & 1.75 & 0.16 & 8.85 \\
\hline 2012 & 6.94 & 1.44 & 0.15 & 8.84 \\
\hline 2013 & 7.26 & 1.44 & 0.14 & 8.84 \\
\hline 2014 & 3.85 & 0.24 & 0.14 & 4.23 \\
\hline
\end{tabular}

Selanjutnya untuk menyatakan hubungan antara luas pertanian dengan jumlah produksi pertanian terdapat pada tabel 2. Jenis hasil pertanian dikelompokkan menjadi 2 kelompok yaitu kelompok pertama adalah tanaman padi dan palawija sedangkan kelompok kedua adalah tanaman sayuran. Kecamatan Denpasar Timur hasil pertanian yang paling tinggi hasil produksinya dari tahun 2011-2014 adalah pada tanaman padi tetapi pada tahun 2014 mengalami penurunan jumlah produksi. 
Tabel 2. Perbandingan Jumlah Produksi Hasil Pertanian di Kecamatan Denpasar Timur

\begin{tabular}{|l|c|c|c|c|}
\hline \multirow{2}{*}{ Nama Tanaman } & \multicolumn{4}{|c|}{ Jumlah Produksi (ton) } \\
\cline { 2 - 5 } & Tahun 2011 & Tahun 2012 & Tahun 2013 & Tahun 2014 \\
\hline Padi & 7427 & 6430 & 7022 & 2294 \\
\hline Jagung & 0 & 0 & 0 & 0 \\
\hline Kedelai & 250 & 246 & 205 & 211 \\
\hline Kacang Tanah & 22 & 22 & 14 & 0 \\
\hline
\end{tabular}

Pada kelompok kedua yaitu tanaman sayur di Kecamatan Denpasar Timur hasil produksi dalam ton per tahun dapat dilihat pada grafik pada gambar 2. Pada gambar terdapat hasil perbandingan produksi tanaman sayur dari tahun 2011-2014, tanaman sayur yang paling tinggi produksinya adalah sayur kangkung dan pada tahun 2014 penurunan hasil produksi tidak signifikan.

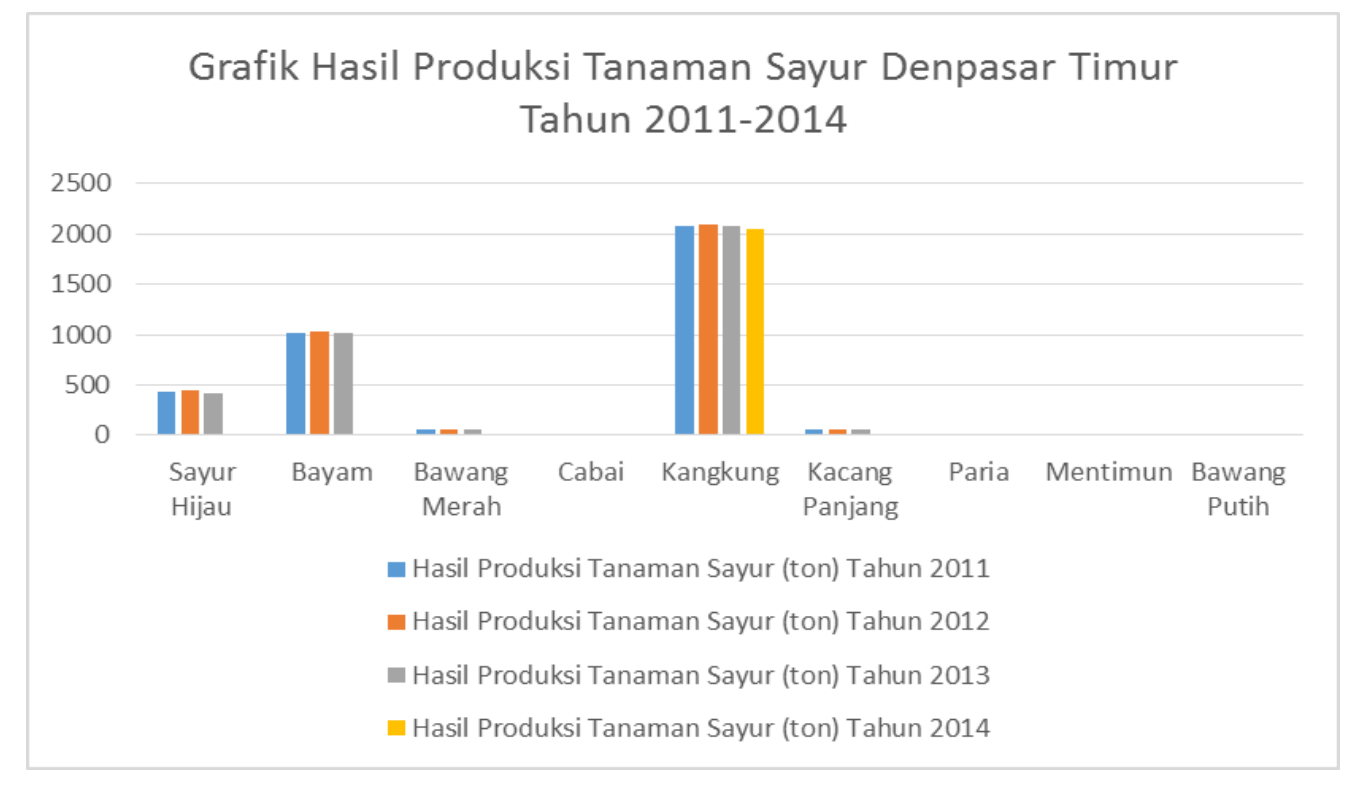

Gambar 2 Grafik Perbandingan Hasil Produksi Tanaman Sayur di Kecamatan Denpasar Timur

Pemetaan hasil pertanian di Kecamatan Denpasar Timur menggunakan software ArcView versi 3.3 yang terdapat pada Gambar 3 .

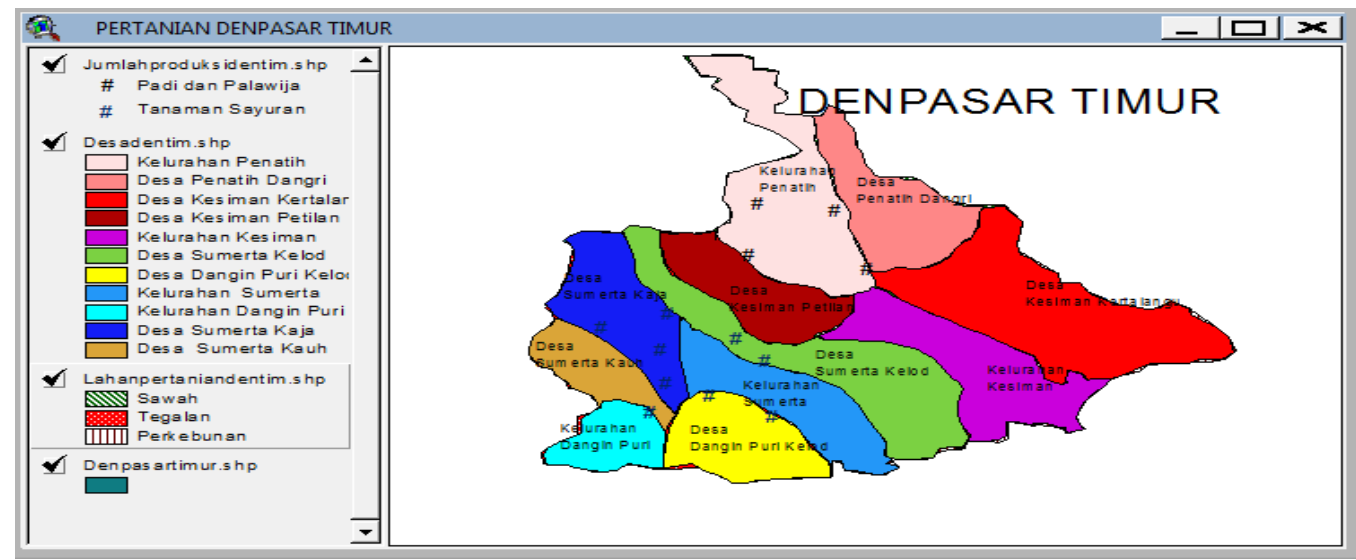

Gambar 3 Hasil Digitasi Hasil Pertanian di Kecamatan Denpasar Timur 
Tabel 3. Perbandingan Luas Lahan Pertanian di Kecamatan Denpasar Barat

\begin{tabular}{|l|c|c|c|c|}
\hline \multirow{2}{*}{ Tahun } & \multicolumn{3}{|c|}{ Jenis Lahan Pertanian $\left(\mathrm{km}^{2}\right)$} & \multirow{2}{*}{ Total $\left(\mathrm{km}^{2}\right)$} \\
\cline { 2 - 4 } & Sawah & Tegalan & Perkebunan & \\
\hline 2011 & 2.56 & 0 & 0 & 2.56 \\
\hline 2012 & 2.56 & 0 & 0 & 2.56 \\
\hline 2013 & 2.843 & 0 & 0 & 2.843 \\
\hline 2014 & 1.353 & 0 & 0 & 1.353 \\
\hline
\end{tabular}

Mengenai jumlah produksi pertanian terdapat pada tabel 4. Pengamatan ini bertujuan untuk mengetahui apakah semakin sempit lahan akan berpengaruh terhadap hasil produksi pertanian di Kecamatan Denpasar Barat. Berdasarkan data pada tabel 4 dilakukan perbandingan jumlah produksi tanaman dari tahun 2011-2014, pada jenis tanaman kelompok pertama terlihat tanaman padi memiliki jumlah produksi yang tertinggi tetapi di tahun 2014 mengalami penurunan jumlah produksi.

Tabel 4. Perbandingan Jumlah Produksi Hasil Pertanian di Kecamatan Denpasar Barat

\begin{tabular}{|l|c|c|c|c|}
\hline \multirow{2}{*}{ Nama Tanaman } & \multicolumn{4}{|c|}{ Jumlah Produksi (ton) } \\
\cline { 2 - 5 } & Tahun 2011 & Tahun 2012 & Tahun 2013 & Tahun 2014 \\
\hline Padi & 3940 & 3497 & 3420 & 1641.19 \\
\hline Jagung & 0 & 0 & 0 & 12.32 \\
\hline Kedelai & 130 & 169.52 & 141.28 & 128.75 \\
\hline Kacang Tanah & 0 & 0 & 0 & 0 \\
\hline
\end{tabular}

Kelompok jenis pertanian kedua yaitu tanaman sayuran di Denpasar Barat dapat dilihat pada grafik pada gambar 3. Berdasarkan grafik tersebut maka dapat disimpulkan bahwa tanaman sayur bayam yang memiliki tingkat produksi paling tinggi sampai tahun 2014.

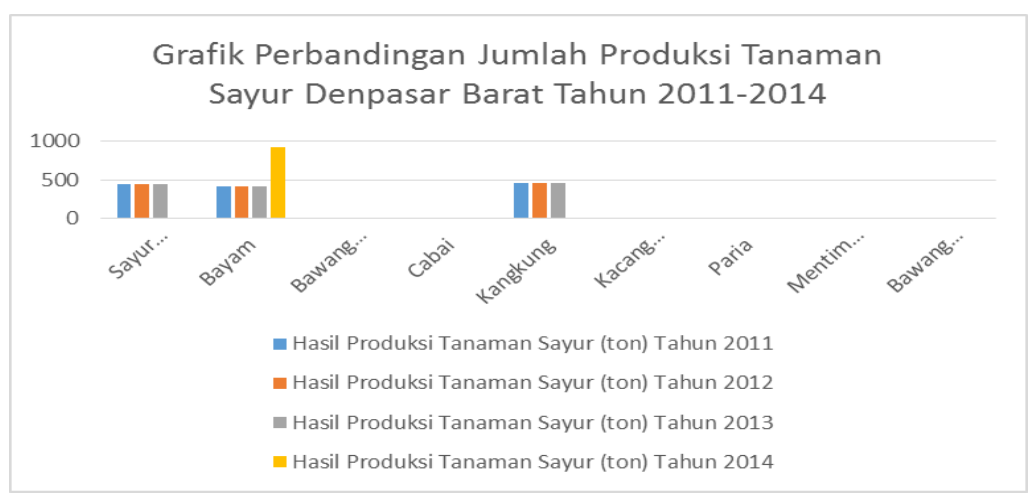

Gambar 3 Grafik Perbandingan Jumlah Produksi Sayur di Kecamatan Denpasar Barat

Data- data yang telah dianalisis yaitu data spasial dan data non spasial di Kecamatan Denpasar Barat dibuatkan pemetaan hasil pertanian dengan menggunakan ArcView seperti gambar

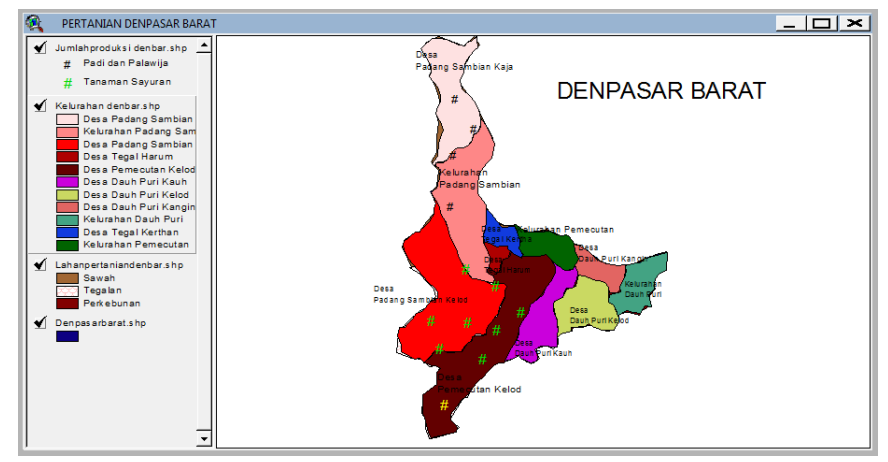

Gambar 4 Hasil Digitasi Peta Hasil Pertanian Denpasar Barat 


\subsection{Hasil Pertanian di Kecamatan Denpasar Utara}

Penelitian ketiga yaitu wilayah pertanian di Kecamatan Denpasar Utara. Perbandingan luas lahan pertanian terdapat pada tabel 5. Data yang diamati dari tahun 2011-2014, luas pertanian di kecamatan ini semakin menyempit setiap tahunnya sedangkan luas wilayahnya $31.42 \mathrm{~km}^{2}$.

Tabel 5. Perbandingan Luas Lahan Pertanian di Kecamatan Denpasar Utara

\begin{tabular}{|l|c|c|c|c|}
\hline \multirow{2}{*}{ Tahun } & \multicolumn{3}{|c|}{ Jenis Lahan Pertanian $\left(\mathrm{km}^{2}\right)$} & Total $\left(\mathrm{km}^{2}\right)$ \\
\cline { 2 - 4 } & Sawah & Tegalan & Perkebunan & \\
\hline 2011 & 7.51 & 0.97 & 0 & 8.48 \\
\hline 2012 & 7.22 & 1.24 & 0 & 8.46 \\
\hline 2013 & 7.715 & 0.69 & 0 & 8.405 \\
\hline 2014 & 4.305 & 0.69 & 0 & 4.995 \\
\hline
\end{tabular}

Perbandingan jumlah produksi pertanian di Kecamatan Denpasar Utara terdapat pada tabel 6. Pada jenis tanaman pertanian kelompok pertama, berdasarkan data perbandingan hasil produksi maka dapat disimpulkan tanaman padi memiliki jumlah produksi yang paling tinggi tetapi di tahun 2014 mengalami penurunan jumlah produksi.

Tabel 6. Perbandingan Jumlah Produksi Hasil Pertanian di Kecamatan Denpasar Utara

\begin{tabular}{|l|c|c|c|c|}
\hline \multirow{2}{*}{ Nama Tanaman } & \multicolumn{4}{|c|}{ Jumlah Produksi (ton) } \\
\cline { 2 - 5 } & Tahun 2011 & Tahun 2012 & Tahun 2013 & Tahun 2014 \\
\hline Padi & 0 & 7724 & 7728 & 2502 \\
\hline Jagung & 0 & 0 & 0 & 0 \\
\hline Kedelai & 0 & 290 & 243 & 130 \\
\hline Kacang Tanah & 0 & 0 & 0 & 0 \\
\hline
\end{tabular}

Kelompok pertanian kedua adalah tanaman sayur, perbandingan jumlah produksi terdapat pada grafik pada gambar 5. Berdasarkan gambar 5. Berdasarkan gambar tersebut, ternyata di Kecamatan ini terdapat 2 jenis sayur yang mempunyai jumlah produksi yang paling tinggi dibandingkan yang lainnya.

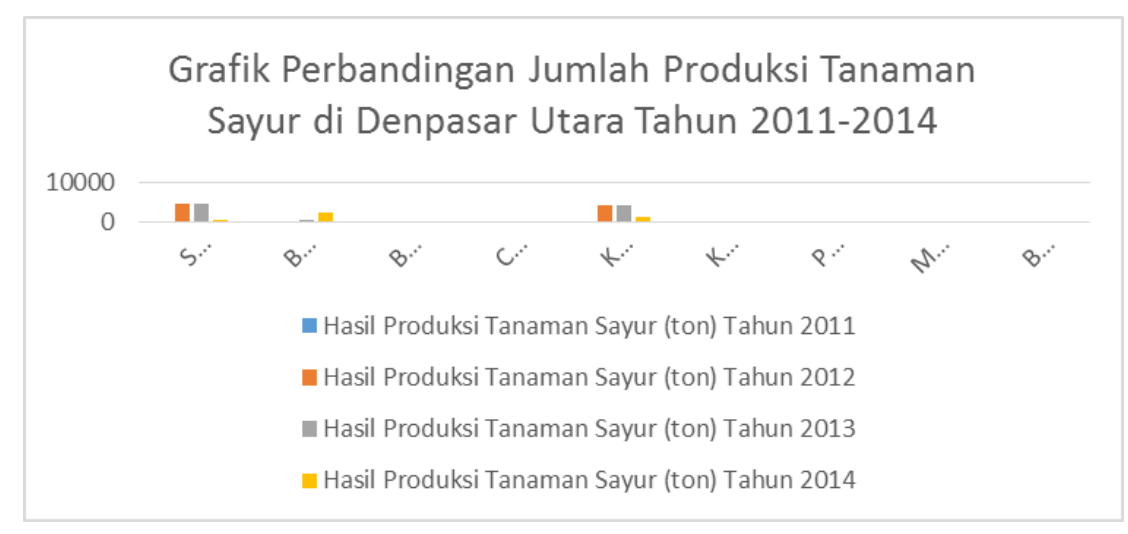

Gambar 5 Grafik Perbandingan Jumlah Produksi Tanaman Sayur di Denpasar Utara

Hasil digitasi spasial dan non spasial Kecamatan Utara terdapat pada gambar 6. Denpasar Utara terdiri dari 11 desa/kelurahan dengan luas pertanian $4.995 \mathrm{~km}^{2}$ pada tahun 2014. 


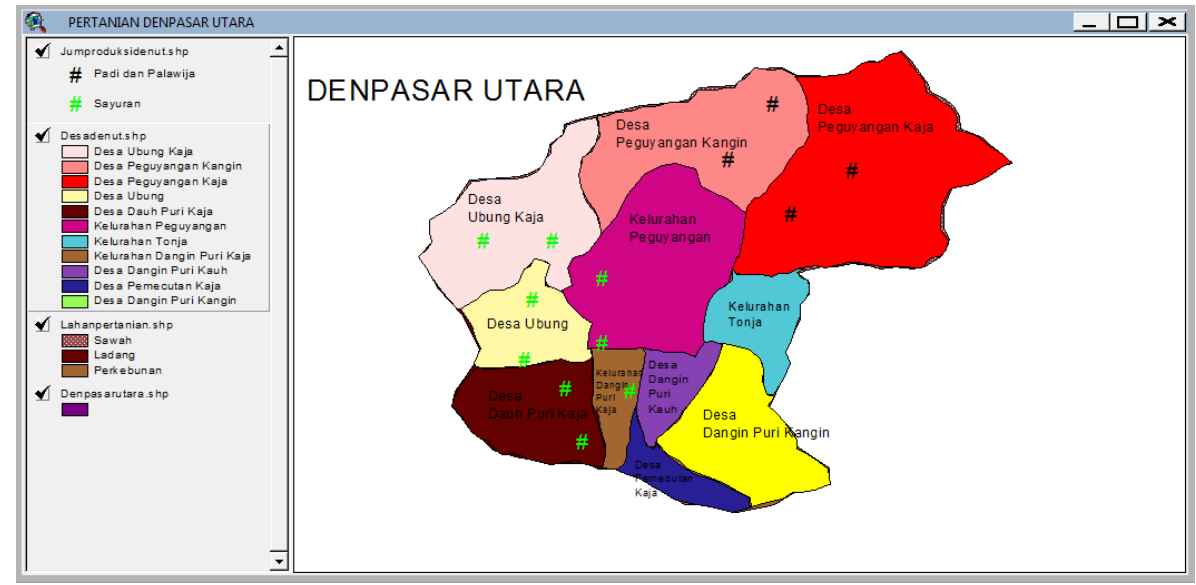

Gambar 6 Hasil Digitasi Peta Hasil Pertanian di Denpasar Utara

\subsection{Hasil Pertanian di Kecamatan Denpasar Selatan}

Pengamatan terakhir dilakukan di Kecamatan Denpasar Selatan, Kecamatan ini mempunyai luas wilayah $49.99 \mathrm{~km}^{2}$. Kecamatan ini memiliki wilayah paling luas diantara kecamatan lainny dan memiliki luas pertanian secara rinci terdapat pada tabel 7. Berdasarkan perbandingan luas lahan pertanian maka dapat dapat disimpulkan luas pertanian semakin menyempit pada tahun 2014, di kecamatan ini tidak terdapat data tegalan dan perkebunan.

Tabel 7. Perbandingan Luas Lahan Pertanian di Kecamatan Denpasar Selatan

\begin{tabular}{|l|c|c|c|l|}
\hline \multirow{2}{*}{ Tahun } & \multicolumn{3}{|c|}{ Jenis Lahan Pertanian $\left(\mathrm{km}^{2}\right)$} & \multirow{2}{*}{ Total $\left(\mathrm{km}^{2}\right)$} \\
\cline { 2 - 4 } & Sawah & Tegalan & Perkebunan & \\
\hline 2011 & 8.96 & 0 & 0 & 8.96 \\
\hline 2012 & 8.47 & 0 & 0 & 8.47 \\
\hline 2013 & 2.843 & 0 & 0 & 2.843 \\
\hline 2014 & 1.353 & 0 & 0 & 1.353 \\
\hline
\end{tabular}

Selanjutnya mengamati jumlah produksi pertanian pada kelompok jenis pertanian pertama, data perbandingan terdapat pada tabel 8 . Hasil analisis dari tabel ini adalah jumlah produksi tanaman yang paling tinggi adalah tanaman padi tetapi pada tahun 2014 terjadi pen urunan yang sangat signifikan.

Tabel 8. Perbandingan Jumlah Produksi Pertanian di Kecamatan Denpasar Selatan

\begin{tabular}{|l|c|c|c|c|}
\hline \multirow{2}{*}{ Nama Tanaman } & \multicolumn{4}{|c|}{ Jumlah Produksi (ton) } \\
\cline { 2 - 5 } & Tahun 2011 & Tahun 2012 & Tahun 2013 & Tahun 2014 \\
\hline Padi & 9308 & 9878 & 9955 & 2517.42 \\
\hline Jagung & 0 & 0 & 0 & 0 \\
\hline Kedelai & 1628 & 371 & 328 & 277 \\
\hline Kacang Tanah & 9 & 9 & 0 & 0 \\
\hline
\end{tabular}

Jenis hasil pertanian pada kelompok 2 yaitu tanaman sayur, untuk data pada Kecamatan Denpasar Selatan terdapat pada gambar 7. Berdasarkan grafik tersebut maka dapat disimpulkan bahwa tanaman sayur yang memiliki jumlah produksi yang tertinggi adalah sayur hijau tetapi hasil produksinya menurun di tahun 2014. 


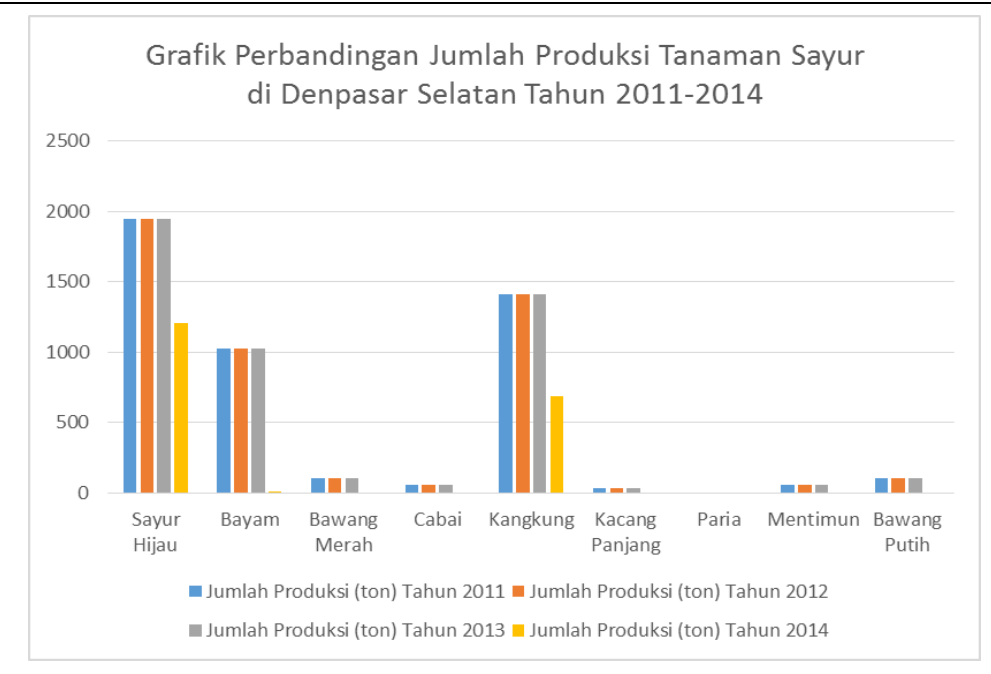

Gambar 7 Grafik Perbandingan Tanaman Sayur di Kecamatan Denpasar Selatan

Hasil digitasi data spasial dan data non spasial terdapat pada gambar 8 sebagai berikut.

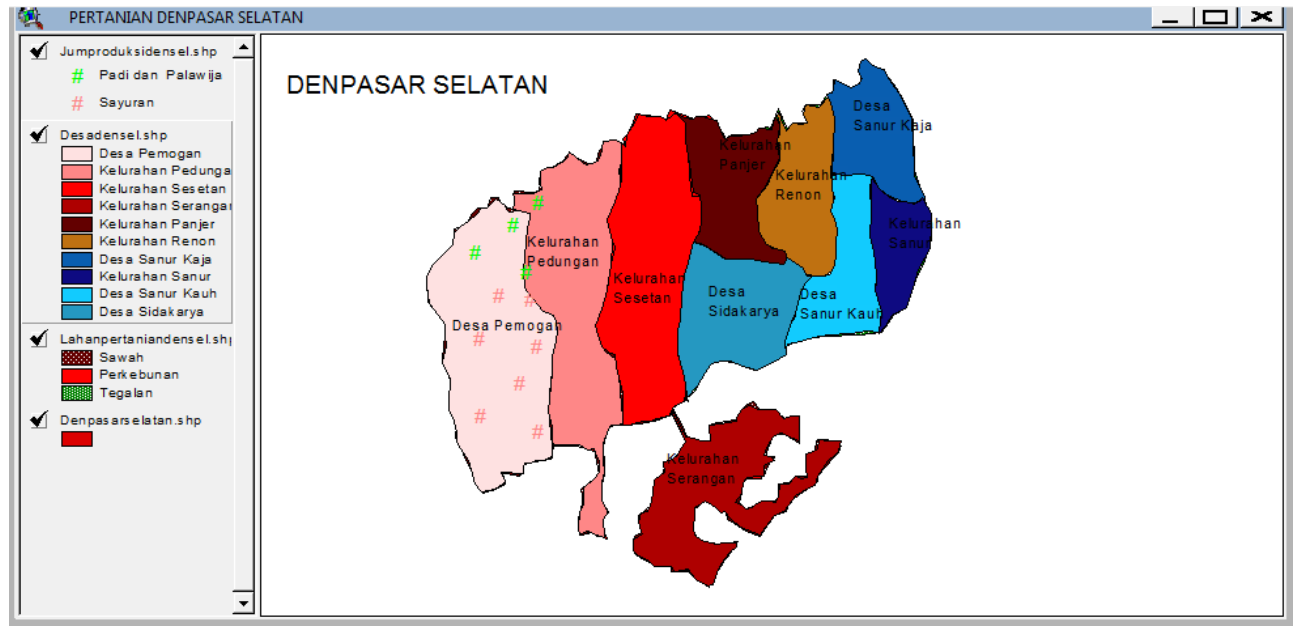

Gambar 8 Hasil Digitasi Peta Pertanian Kecamatan Denpasar Selatan

\section{Pembahasan}

Berdasarkan analisis yang sudah dilakukan mengenai mengelompokkan jenis lahan pertanian menjadi 3 yaitu lahan sawah, lahan tegalan dan lahan perkebunan. Berdasarkan penelitian bahwa di Kecamatan Denpasar Timur dengan luas wilayah $22.31 \mathrm{~km}^{2}$ pada tahun 2013 berdasarkan data statistic sedangkan lahan pertanian yang dimiliki tahun 2011 adalah $8.85 \mathrm{~km}^{2}$, tahun 2012 luas pertanian kurang lagi 0.01 yaitu sekitar $8.84 \mathrm{~km}^{2}$, tahun 2013 luasnya tetap $8.84 \mathrm{~km}^{2}$ sedangkan pada tahun 2014 lahan pertanian turun sekitar $4.61 \mathrm{~km}^{2}(52.15 \%)$. Penurunan lahan pertanian ini sangat signifikan dan menjadi peringatan pemerintah untuk melakukan analisis ke lapangan penyebab menyempitnya lahan pertanian. Bila dibandingkan dengan luas wilayah Denpasar Timur pada tahun 2013 yaitu 22.31 dengan luas lahan pertanian tahun 2014 yaitu $4.23 \mathrm{~km}^{2}$ maka luas yang bukan untuk lahan pertanian adalah $18.08 \mathrm{~km}^{2}$ berarti luas pertanian $18.96 \%$ dari luas wilayah sisanya sekitar $81.04 \%$ adalah lahan untuk pemukiman dan lahan di luar pertanian.

Berdasarkan pengelompokkan jenis tanaman pertama yaitu tanaman padi dan palawija di Denpasar Timur, sesuai data badan statistik maka tanaman yang menghasilkan jumlah produksi yang terbesar adalah tanaman padi dan tanaman kedelai. Hasil produksi tanaman padi dalam ton per tahun dari tahun 2011-2014 secara berurutan yaitu 7427, 6430, 7033 dan 
2294. Pada tahun 2014 tanaman padi mengalami penurunan yang signifikan sekitar $67.38 \%$, sedangkan untuk tanaman kedelai hasil produksi dalam ton per tahun secara berurutan dari tahun 2011-2014 yaitu 250, 246, 205 dan 211. Tanaman kedelai mengalami kenaikan dan penurunan, penurunan terjadi di tahun 2012 dan 2013 sedangkan tahun 2014 mengalami kenaikan hanya $2.9 \%$. Tanaman sayuran kangkung mempunyai jumlah produksi yang paling tinggi dibandingkan jenis sayuran yang lainnya, jumlah produksi berturut-turut dari tahun 20112014 adalah 2085, 2090, 2084 dan 2050 ton per tahun, berdasarkan data tersebut sayuran kangkung mengalami penurunan jumlah produksi hanya $1.6 \%$ saja. Berdasarkan hasil analisis hasil pertanian di Kecamatan Denpasar Timur maka dapat disimpulkan antara luas area pertanian dengan jumlah produksi pertanian berbanding lurus artinya semakin sempit area pertanian maka hasil produksinya semakin sedikit pula.

Kecamatan Denpasar Utara memiliki luas wilayah sekitar $31.42 \mathrm{~km}^{2}$ pada tahun 2013. Luas lahan pertanian secara berurutan 2011, 2012, 2013 dan 2014 yaitu $8.48 \mathrm{~km}^{2}, 8.46 \mathrm{~km}^{2}, 8.405$ $\mathrm{km}^{2}$ dan $4.995 \mathrm{~km}^{2}$. Berdasarkan data tersebut, luas lahan pertanian mengalami penurunan yang signifikan di tahun 2014 yaitu sekitar $3.41 \mathrm{~km}^{2}$ dari tahun sebelumnya, persentase penurunannya sekitar $40.57 \%$. Jika dibandingkan dengan luas wilayah dengan luas pertanian pada tahun terakhir penelitian maka luas pertanian hanya sekitar $15.9 \%$ sisanya $84.1 \%$ adalah lahan pemukiman atau lahan di luar pertanian.

Mengenai jumlah produksi tanaman pertanian di Kecamatan Denpasar Utara adalah pertama untuk tanaman padi dengan jumlah produksi dalam ton per tahun secara berurutan dari tahun 2011-2014 adalah 0, 7724, 7728 dan 2502. Pada tahun 2011 daerah ini sama sekali tidak menghasilkan sedangkan untuk tahun selanjutnya mengasilkan tetapi selalu mengalami penurunan, penurunan yang signifikan terdapat pada tahun 2014 yaitu sebesar $67.6 \%$. Hasil produksi jenis pengelompokkan yang kedua yaitu tanaman sayur, tanaman sayur yang menghasilkan adalah tanaman bayam dan kangkung, untuk sayuran bayam mengalami kenaikan sedangkan sayur kangkung mengalami penurunan sebesar $71.1 \%$. Jadi kesimpulannya luas area pertanian berpengaruh terhadap hasil produksi.

Pembahasan selanjutnya adalah Kecamatan Denpasar Barat, kecamatan ini memiliki luas wilayah $24.06 \mathrm{~km}^{2}$ pada tahun 2013. Luas lahan pertanian sesuai dengan pengelompokkan lahan maka pada tahun 2011-2014 secara berurutan adalah $2.56 \mathrm{~km}^{2}, 2.56 \mathrm{~km}^{2}, 2.843 \mathrm{~km}^{2}$ dan $1.353 \mathrm{~km}^{2}$. Luas lahan pertanian pada kecamatan ini lebih sedikit dibandingkan dengan luas lahan pertanian di kecamatan yang lain. Penurunan luas lahan pertanian mulai dari tahun 2013 yaitu sekitar $0.283 \mathrm{~km}^{2}$ dan pada tahun 2014 terjadi penurunan lahan pertanian sekitar 1.49 $\mathrm{km}^{2}$. Luas lahan pertanian pada tahun terakhir yaitu $5.62 \%$ dari luas wilayah secara keseluruhan, jadi sisanya $94.38 \%$ adalah lahan pemukiman dan lain-lain.

Mengetahui hubungan antara luas pertanian dengan jumlah produksi pertanian di Kecamatan Denpasar Barat maka pembahasan selanjutnya adalah mengenai hasil produksi pertanian, mulai dari tanaman padi. Hasil produksi tanaman padi dalam ton per tahun dari tahun 20112014 secara berturut-turut adalah 3940, 3497, 3420 dan 1641.19. Berdasarkan data hasil pertanian padi maka dapat disimpulkan bahwa penurunan signifikan terjadi pada tahun 2014 sebesar $52 \%$ sedangkan untuk tanaman kedelai sebagai penghasil setelah padi sebesar secara berurutan adalah 130, 169.52, 141.28 dan 128.75, berdasarkan data tersebut maka dapat disimpulkan bahwa hasil produski tanaman kedelai mengalami kenaikan dan penurunan, kenaikan terjadi di tahun 2012 sedangkan penurunan terjadi di tahun 2013 dan tahun 2014 sekitar berturut-turut adalah $16.7 \%$ dan $8.9 \%$. Hasil produksi untuk pengelompokkan jenis tanaman kedua adalah tanaman sayur.

Tanaman sayur yang menghasilkan di Kecamatan Denpasar Barat adalah bayam, sayur hijau dan kangkung, diantara ketiga sayur tersebut hanya bayam yang mengalami kenaikan jumlah produksi sedangkan tanaman yang lain mengalami penurunan. Berdasarkan hasil analisis tersebut maka dapat disimpulkan secara keseluruhan dengan luas pertanian yang sempit sangat mempengaruhi jumlah produksi pertanian.

Kecamatan Denpasar Selatan, kecamatan ini memiliki luas wilayah secara keseluruhan pada tahun 2013 yaitu $49.99 \mathrm{~km}^{2}$, kecamatan ini memiliki luas yang paling tinggi dibandingkan 
dengan kecamatan lainnya. Luas pertanian pada kecamatan ini dari tahun 2011-2014 secara berurutan adalah $8.96 \mathrm{~km}^{2}, 8.47 \mathrm{~km}^{2}, 2.843 \mathrm{~km}^{2}, 1.353 \mathrm{~km}^{2}$. Penurunan luas lahan pertanian turun secara siginifikan mulai tahun 2013 yaitu $5.627 \mathrm{~km}^{2}$ dan tahun 2014 turun menjadi 1.49 $\mathrm{km}^{2}$. Berdasarkan data tersebut luas lahan pertanian pada tahun 2014 yaitu sekitar $2.7 \%$ dari luas wilayah sisanya sekitar $97.3 \%$ adalah lahan pemukiman dan lahan untuk fungsi yang lain.

Mengenai jumlah produksi di Kecamatan Denpasar Selatan, berdasarkan data yang telah diamati dari tahun 2011-2014 sesuai dengan pengelompokkan jenis tanaman pertanian, untuk tanaman padi terjadi penurunan jumlah produksi dalam ton per tahun dari tahun 2011-2014 secara berurutan yaitu 9308, 9878, 9955 dan 2517.42. Penurunan produksi tanaman padi secara signifikan terjadi pada tahun 2014 sekitar $74.7 \%$, angka yang sangat tinggi sekali lebih dari $50 \%$ penurunan produksinya. Tanaman palawija yang dihasilkan di Denpasar selatan adalah kedelai dengan jumlah produksi dalam ton per tahun dari tahun 2011-2014 secara berurutan yaitu 1628, 371, 328 dan 277. Berdasarkan data tersebut maka dapat disimpulkan produksi kedelai selalu mengalami penurunan yang signifikan pada tahun 2012 yaitu sekitar $77.2 \%$ sedangkan untuk tahun 2014 penurunan produksinya $15.55 \%$.

Hasil produksi berdasarkan kelompok kedua yaitu sayuran, sayuran yang paling menghasilkan ada 2 yaitu sayur hijau dan sayur kangkung. Sayuran hijau yang paling tinggi hasil produksinya dibandingkan dengan sayuran yang lain. Hasil produksi sayuran hijau dalam ton per tahun dari tahun 2011-2014 secara berurutan yaitu 1946, 1946, 1948 dan 1211.02. Berdasarkan data tersebut, terjadi penurunan hasil produksi dari tahun ke tahun, penurunan hasil produksi yang paling signifikan di tahun 2014 yaitu sekitar $37.83 \%$ sedangkan pada tahun lainnya penurunannya hanya sedikit. Penghasil sayuran dengan jumlah produksi paling tinggi kedua yaitu sayur kangkung, sayuran ini menghasilkan produksi dalam ton per tahun dari tahun 2011 2014 secara berurutan yaitu 1415, 1415, 1415 dan 691.44. Penurunan hasil produksi yang signifikan pada tahun 2014 yaitu sekitar $51.13 \%$. Berdasarkan data-data yang telah dianalisis maka dapat disimpulkan penurunan lahan yang signifikan pada tahun 2014 yang diikuti dengan penurunan jumlah produksi tanaman terutama tanaman bahan pokok yaitu padi yang semakin lama semakin berkurang seiring dengan lahan pertanian yang semakin menyempit.

\section{Kesimpulan}

1. Luas Area pertanian di masing-masing Kecamatan mengalami penurunan, terutama di tahun 2014 mengalami penurunan yang signifikan

2. Jumlah produksi tanaman pokok terutama padi selalu mengalami penurunan setiap tahunnya, penurunan yang paling signifikan di tahun 2014

3. Luas area pertanian berpengaruh terhadap jumlah produksi pertanian, secara keseluruhan dapat disimpulkan semakin sempit wilayah pertanian maka jumlah produksi pertanian semakin berkurang

4. Sistem Infomasi Geografi ini dengan menggunakan tools ArcView sangat membantu secara efektif menghasilkan informasi mengenai hasil analisi pertanian, informasi ini dapat digunakan oleh pemerintah sebagai bahan kajian untuk mensukseskan pertanian dan menyelematkan tanah pertanian dari alihfungsi yang lain

\section{Daftar Pustaka}

Denpasar, P. k. (2015, Juni 22 ). Profil Kota Denpasar. Retrieved from Pemerintah Kota Denpasar: www.denpasarkota.go.id

Heddy, S. (2010). Agrosistem : Permasalahan Lingkungan Pertanian. Jakarta: Raja Grafindo.

Pertanian, K. (2013). Statistik Lahan Pertanian. Jakarta: Pusat Data dan Sistem Informasi Pertanian Sekretariat Jenderal Kementerian Pertanian.

Prahasta, E. (2005). Sistem Informasi Geografi (konsep-konsep dasar). Bandung: Informatika Bandung. 
Prahasta, E. (2004). Sistem Informasi Geografi : ArcView Lanjut. Bandung: Informatiaka Bandung.

Prahasta, E. (2002). Sistem Informasi Geografis : Tutorial ArcView. Bandung: Informatika Bandung.

Statistik, B. P. (2015, November 1). Badan Pusat Statistik Provinsi Bali. Retrieved from BPS Web site: http://www.bps.go.id/ 